\title{
Det mytologiska \\ självskadebeteendet \\ Könade stereotyper och idealtypiska \\ berättelser
}

\section{CHRISTIAN STÅHL}

Självskadebeteende betraktas genomgående som ett stjejproblem«. Syftet med artikeln är att problematisera den utgångspunkten genom att kritiskt granska tidigare forskning i jakt på ursprunget till den stereotypa självskadaren. Femininitetsdiskursen framstår här som ett centralt element $i$ skapandet av en identitet som självskadare.

Den gängse bilden av en person med självskadebeteende, inom forskning, populärvetenskap och massmedier, är en vit tonårstjej. ${ }^{1}$ Trots att studier visat på att beteendet förekommer bland killar i större utsträckning än vad som tidigare antagits vissa studier hävdar att fördelningen skulle kunna vara helt jämn (Matsumoto et al. 2005, Taylor 2003) - lever denna stereotyp kvar inom alla fält. Bilden av den vita tonårstjejen som självskadebeteendets sinne-

Christian Ståhl, fil.mag i sociologi, doktorand på Rikscentrum för arbetslivsinriktad rehabilitering, Institutionen för medicin och hälsa vid Linköpings universitet. bild växte fram i psykiatrisk forskning under 1960- och 70-talen, och många studier som sedan genomförts har på ett oreflekterat sätt reproducerat denna bild, och utgått från att den överensstämmer med verkligheten (Brickman 2004). Det ligger

1 Jag använder mig genomgående av benämningarna "tjej» och "kille», då "flicka» och "pojke» antyder att det handlar om barn, medan "kvinna» och "man» antyder vuxna personer. Jag har uppfattat benämningarna "tjej» och "kille» som någonstans däremellan, alternativt omfattande såväl barn som vuxna. Då jag refererar till forskning använder jag dock de benämningar som förekommer i de aktuella texterna. 
därför nära till hands att utifrån befintlig rapportering och forskning dra slutsatsen att självskadebeteende är ett tjejproblem. Syftet med artikeln är att problematisera denna slutsats. Detta görs genom att studera hur den självskadande tonårstjejen framställdes i de tidiga inflytelserika artiklarna och hur den bilden fortlever i den svenska forskningen, samt genom att diskutera vilka konsekvenser en sådan föreställning kan tänkas få för tjejer och killar med självskadeproblematik. Centralt för diskussionen är hur de normativa förväntningarna på kön påverkar hur ungdomars identiteter, kroppar och beteenden bemöts och tolkas i vården, forskningen och samhället i stort.

Först några ord angående artikelns disposition. Inledningsvis gör jag en beskrivning av den teoretiska utgångspunkten, där jag introducerar begrepp som är relevanta för diskussionen. Sedan vidtar en presentation av självskadebeteende, så som det beskrivs i ofta refererad litteratur. Därefter granskar jag ett antal tidiga studier av självskadebeteende för att sedan analysera den svenska forskningen. Artikeln avslutas med en teoretisk diskussion kring fynden.

Urvalet av artiklar och studier som granskats har skett på två vis. I granskningen av den internationella forskningen har fokus legat på de studier som haft störst inflytande på senare forskning, vilket innebär att jag i mitt urval utgått från de studier som oftast förekommer i referenslistor och forskningsgenomgångar. En artikel av Barbara Brickman (2004) har till viss del fungerat vägledande i detta urval, då hennes artikel problematiserar könsaspekten i forskningen om självskadebeteende. Urvalet av den svenska forskningen har skett annorlunda, då denna forskning är mycket knapphändig. Här har merparten av befintlig forskning på området inkluderats i studien, och kontrasterats mot den internationella forskningen.

Jag gör i artikeln inga anspråk på att kunna uttala mig om könsfördelningen kring självskadebeteende, och jag motsäger heller inte den föreslagna övervikten av tjejer. Den frågan lämnar jag obesvarad, då det inte ligger i artikelns syfte att besvara den. Artikelns syfte är istället att problematisera en könsfördelning som många gånger accepteras som empirisk, trots att den inte kunde beläggas. Detta görs genom en granskning av de tolkningsmodeller och förklaringar som förts fram - och till stor del fortfarande förs fram - som diskuterar självskadebeteendet som något exklusivt feminint. En tänkbar konsekvens av detta är att den alltmer stereotypa bilden av vem självskadaren är i sig skapar dessa tjejer: ju oftare bilden presenteras, desto fler blir tjejerna. På så vis fungerar stereotypen självuppfyllande.

\section{Maskulinitet och femininitet hos ungdomar: en teoretisk utgångspunkt}

Maskulinitet och femininitet är begrepp som traditionellt förknippats med den manliga respektive kvinnliga kroppen. Det finns emellertid en strävan att skilja begreppen från de biologiska könen, för att istället tillåta en diskussion där maskulinitet och femininitet är element som existerar såväl hos kvinnor som hos män: såväl kvinnlig maskulinitet som manlig femini- 
nitet (Nordberg 2004, Halberstam 1998). Att tydligare skilja dessa begrepp från de biologiska könen leder till att den sociala konstruktionen av maskulina och feminina stereotyper kan diskuteras på ett friare sätt. Begreppen innefattar dock en inbyggd svårighet, då de inte går att använda utan att tänka på ett könsdikotomt sätt. Oavsett om de förknippas med de biologiska könen eller inte är de fast i en polarisering mellan å ena sidan maskulint, och å andra sidan feminint. Även om vi diskuterar maskulinitet hos kvinnor eller femininitet hos män förblir dessa egenskaper bundna till den traditionella könsdikotomin; det som kan särskiljas är kön och genus, biologiskt och socialt. Dock vore det såväl förhastat som poänglöst att av denna anledning överge begreppen som analytiska redskap.

I denna artikel används begreppen maskulinitet och femininitet som knippen av tolkningsmönster kring beteenden och uttryck, där ett givet fenomen kan betraktas på en tänkt skala från fullständigt maskulint till fullständigt feminint. I artikeln vill jag identifiera var tidigare forskare placerat självskadebeteendet på en sådan skala. "Feminina» och "maskulina" tolkningsmönster är inte nödvändigtvis knutna till de biologiska könen, men då de generellt förknippas med kvinnor och män bidrar de till att skapa könade - högst normativa - förväntningar för hur en kille eller en tjej ska agera. Reproduktionen av dessa förväntningar på maskulinitet och femininitet är ett betydande inslag i hur kön socialt konstrueras. Halberstam hävdar att alla tonårstjejer påtrycks en tvångsmässig femininitet, där enbart beteenden och uttryck som överensstämmer med de nor- mativa förväntningarna är tillåtna (Halberstam 1998).

Den sociala konstruktionen av genus är därmed inte statisk, utan en ständigt föränderlig process, som sker i interaktioner och relationer mellan människor och strukturer. Detta är en teoretisk utgångspunkt som kan hänföras till beteckningen doing gender, på svenska ofta översatt med "att göra kön». Denna ansats innehåller flera olika synsätt, däribland det etnometodologiska, det kulturella och det processuella (Eriksson 2005). I artikeln kommer jag att utgå ifrån att konstruktionen av kön är processuell, vilket innebär att genus - i form av föreställningar, praktiker och vanor skapas i praktiskt taget all interaktion, och att genusrelationer är närvarande i all social organisering. Maskulinitet och femininitet är enligt detta synsätt någonting som hela tiden skapas och återskapas.

I en studie av så kallade §12-hem diskuterar Andersson hur tjejers och killars beteende tolkas och behandlas på olika sätt, där tjejers problem generellt betraktas vara av psykologisk/psykiatriskart,medan killarnas ses som sociala (Andersson 1997). Tjejernas problem definieras utifrån en psykopatologisk diskurs, som skapar bilden av den inåtvända tjejen och den utåtagerande killen. Hon menar vidare att de eventuella skillnader som kan noteras mellan könen upphör när vi studerar de sociala bakgrundsförhållandena. Hilte och Claezon utvecklar dessa tankar i sin studie av kön på ungdomsinstitutioner (2005). Killarnas ilska uppfattas av personalen som en protest mot att ha placerats på institution, medan tjejers självskadebeteende tolkas som ett tecken på en psykisk problematik. Författarna menar att 
även tjejernas beteende kan betraktas som en protest mot institutionsplaceringen, uttryckt i enlighet med de traditionella och könade förväntningarna - socialt skapade förväntningar som knyts till det biologiska könet - på dem som emotionella tjejer. Att beteendet istället tolkas som ett tecken på psykiska problem är enligt författarna ett uttryck för den psykopatologiska diskursen, där tjejernas problem betraktas som mer allvarliga och komplexa än killarnas, som på ett förenklat sätt reduceras till sociala svårigheter.

Carolina Överlien (2006) noterar i en artikel hur unga kvinnor, 14-20 år, på slutna ungdomshem genomgående förses med en speciell form av sexuell identitet. Personalen talar om de intagna kvinnorna på två sätt, som asexuella barn och som offer för sexuella övergrepp. Överlien menar att könsnormer på dessa ungdomshem blir till kontroll och disciplin, vilket gör den sexuella identiteten till institutionernas överordnade organisatoriska princip. Hon påpekar även att samtliga tre kriterier för omhändertagande - drogmissbruk, kriminalitet och socialt nedbrytande beteende - tolkas olika utifrån ungdomens kön, där det sexuella beteendet för flickor utgör en grund för omhändertagande, vilket inte är fallet för pojkar.

Det har påvisats att endast ett fåtal av de som skadat sig själva söker vård (Samuelsson 2004), och att manliga självskadare lättare hamnar utanför statistiken (Taylor 2003). Det finns därmed anledning att anta att mörkertalet bland killar med hjälpbehov kan vara större än hos tjejer.

\section{Vad är självskadebeteende?}

I detta avsnitt ämnar jag ge en inledande bild av vad självskadebeteende är, och något generaliserat - hur det beskrivs och tolkas. Under de nästkommande rubrikerna kommer jag att kritiskt granska dessa förklaringars utgångspunkter.

Självskadebeteende bland unga har rönt stor uppmärksamhet de senaste åren, och brukar definieras som ett medvetet skadande av den egna kroppen utan suicidavsikt (Favazza 1996, Simeon \& Favazza 2001). Det finns flera indikatorer på att självskadebeteende ökar i omfattning bland ungdomar, även i Sverige (se t.ex. Socialstyrelsen 2005, 2006, BRIS 2005). Forskningen kring självskadebeteende är dock, i synnerhet i Sverige, mycket knapphändig. Socialstyrelsens forskningsöversikt visar på stora kunskapsluckor även internationellt: det saknas främst pålitliga studier av beteendets utbredning, samt kring behandlingsformer (Socialstyrelsen 2004b).

En av de främsta auktoriteterna inom forskningen kring självskadebeteende är tvivelsutan den amerikanske psykiatern Armando Favazza. Han publicerade 1987 boken Bodies Under Siege: Self-Mutilation and Body Modification in Culture and Psychiatry (omarbetad 1996), som kommit att bli en central referens på området. Favazza skiljer mellan kulturellt sanktionerat och patologiskt självskadebeteende. Kulturellt sanktionerat, ofta ritualiserat, självskadebeteende (såsom omskärelse, tatueringar och piercingar) betraktas i de kulturer där det förekommer generellt som handlingar med stort symboliskt värde. Patologiskt självskadebeteende, å sin sida, betraktas negativt av 
den omgivande kulturen, saknar kulturell mening och utförs av ett fåtal av dess medlemmar (Favazza 1996). Det patologiska självskadebeteendet indelas av Simeon och Favazza i fyra huvudsakliga kategorier: stereotypt (stereotypic), grovt (major), tvångsmässigt (compulsive), samt impulsivt (impulsive) (Simeon \& Favazza 2001). Det stereotypa och det grova självskadebeteendet förknippas generellt med svårare psykiska sjukdomar och utvecklingsstörningar, medan det tvångsmässiga och det impulsiva självskadebeteendet förknippas med olika former av personlighets- och impulskontrollstörningar. Det impulsiva självskadebeteendet har av Favazza delats upp i två underkategorier, episodiskt och repetitivt, där de vanligaste uttrycken är skärande $\mathrm{i}$ och brännande av huden (Favazza 1996). Det impulsiva självskadebeteendet är det som oftast avses när begreppet självskadebeteende används.

En stor del av den senare forskning som finns kring självskadebeteende grundar sig på Favazzas klassificering, och riktar sig främst mot det han beskriver som den episodiska och den repetitiva formen av impulsivt självskadande. Dock finns fortfarande ingen allmänt accepterad terminologi på området; två vanliga termer som brukar beteckna ungefär det ovan beskriva beteendet är deliberate self-harm (DSH) och selfinjurious behavior (SIB). I Socialstyrelsens forskningsöversikt (2004b) används främst SIB. (DSH översätts där till självdestruktivitet och beskrivs som bredare, även innefattande ätstörningar, alkohol- och drogmissbruk.)

Socialstyrelsens rapport pekar på att tjejer är överrepresenterade bland ungdo- mar med självskadeproblematik, men samtidigt att mörkertalet av allt att döma är stort (Socialstyrelsen 2004a). En senare rapport från Socialstyrelsen anger att sjukvårdens kontakter med ungdomar med självmordseller självskadebeteende ökat kraftigt de senaste åren, speciellt bland unga tjejer; ökningen gäller dock för båda könen (Socialstyrelsen 2006). Rapporterna har endast undersökt de ungdomar som söker vård, och det är oklart om de killar som delar denna problematik söker vård i samma utsträckning som tjejer, eller om mörkertalet här är större. Studier har visat att endast ett fătal av de som uppger att de skadat sig själva sökt vård (Samuelsson 2004). Enligt Taylor är det vanligare att manliga självskadare inte kommer med i statistiken, eftersom deras skador oftare diagnosticeras som olycksfall (Taylor 2003).

I en engelsk studie från 2002, baserad på 6020 skolelever, angav elva procent av tjejerna och tre procent av killarna att de skadat sig själva, och en norsk studie från 2003 ger liknande siffror (Socialstyrelsen 2004b). En svensk enkätundersökning av 2969 skolelever visade att tio procent av tjejerna och fem procent av killarna skadat sig själva; bland de elever som rapporterade att detta skett ofta ( $2 \%$ ) fanns emellertid ingen skillnad mellan könen (Sandberg 2001). Flera studier pekar på att manligt självskadebeteende förekommer i större utsträckning än vad som tidigare antagits (Matsumoto et al. 2005, Taylor 2003). Enstaka exempel finns även på äldre studier där könsfördelningen uppges vara jämn (Pattison \& Kahan 1983). 


\section{Den tidiga forskningen - stereotypen etableras}

Brickman behandlar i en artikel kring självskadebeteendets vetenskapliga beskrivning hur forskningen skapat bilden av självskadaren som en attraktiv vit tonårstjej (Brickman 2004). Utifrån hur femininitet och den kvinnliga kroppen historiskt patologiserats beskriver hon hur den traditionella bilden av kvinnokroppen som vacker, skör och passiv fungerat som utgångspunkt för hur självskadebeteende tolkats och förklarats. 1961 hamnar självskadebeteende första gången i fokus, i en studie av 121 självskadare, varav 93 kvinnliga och 28 manliga. Under den andra halvan av 1960talet publiceras flera artiklar där beteendet beskrivs och tolkas, och det är i dessa artiklar som bilden av beteendet som ett kvinnligt fenomen etableras; artiklarna beskriver vem självskadaren är, vad hon gör och varför hon gör det. Här etableras bilden av en ung, attraktiv kvinna som är intelligent och begåvad, och på ytan framstår som "normal«. Hon beskrivs vidare som antingen promiskuös eller överdrivet rädd för sex (Brickman 2004).

Graff och Mallin (1967) formulerar i en artikel denna bild kanske allra tydligast:

In summary, the cutter is an attractive, intelligent, unmarried young woman, who is either promiscuous or overly afraid of sex, easily addicted, and unable to relate successfully to others. She is an older one in a group of siblings with a cold, domineering mother and a withdrawn, passive, hypercritical father. She slashes her wrists indiscriminately and repeatedly at the slightest provoca- tion, but she does not commit suicide. She feels relief with the commision of her act (Graff \& Mallin 1967 s. 38).

Graff och Mallin antyder i en passus ett socialkonstruktionistiskt inslag, då de konstaterar att beteendemönstret för självskadare oftast förklaras "by the fact that a girl is trained to be more passive than a boy“ (Graff \& Mallin 1967 s. 40). I de följande meningarna konstaterar de dock att de kvinnor de undersökt "had great passive longings satisfied by techniques unacceptable to a male", samt en spekulation kring att flickor generellt stöts bort av sina mödrar mer frekvent än pojkar (Graff \& Mallin 1967 s. 40). De påpekar att de kvinnor som studerats uppvisar många likheter med tonåriga manliga mördare, vilka emellertid hanterade sina aggressioner på ett mera "maskulint» sätt.

I Ping-Nie Paos artikel »The Syndrome of Delicate Self-cutting" (1969) görs en indelning av självskadarna i å ena sidan "coarse", och å andra sidan »delicate«. Av de 32 självskadare han undersökt var 27 "delicate", och 23 av dessa var kvinnor. Pao återger den tidigare etablerade bilden av självskadaren som en på ytan framgångsrik ung kvinna. De orsaker som han identifierar är emellertid mera suggestiva än vad som tidigare framlagts. Hans tes är att beteendets orsak främst handlar om en osäkerhet kring den sexuella identiteten. Enligt Pao finns det en utvecklad önskan hos de undersökta kvinnorna att vara män, eller åtminstone att åstadkomma jämlikhet mellan könen och få tillträde till manliga yrkesområden. Efter terapi inser emellertid patienterna att denna önskan bottnar i moderns bristande

Christian Ståhl: Det mytologiska självskadebeteendet. 
omvårdnad och förnekelse av sin femininitet, och med den nya insikten kan patienterna slutligen släppa sin önskan att tävla med män, och även tillåta sig att klä sig "feminint" (Pao 1969 s. 201). Detta tolkar Pao på ett freudianskt sätt:

[I] t was unmistakable that her primary struggle then was concerned with her penis envy and her anxiety about castration. Cutting seemed to be a symbolic expression of denied, yet accepted, castration. If the above be contributory to the general psychology of all cutters, it becomes understandable that cutting, as a symptom, should occur more often in females (Pao 1969 s. 201f.).

Onekligen. De män som ingick i studien beskrivs å sin sida som "pretty boys", och betraktas likaså som sexuellt vilsna.

Fokuseringen på den kvinnliga sexualiteten återkommer i senare artiklar. Sexuell förvirring beskrivs hos Rosenthal et al. (1972) som ett framträdande drag hos självskadarna: de identifierar sig hellre med sina fäder än sina mödrar, och de tycks obekväma med sin sexualitet, då de ofta tar avstånd från sin femininitet. De män som förekommer exkluderas efter hand ur studien, då fynden visade sig vara så pass annorlunda jämfört med de för kvinnorna. Sett till det tolkningsförslag som ges till kvinnornas beteende - menstruationsångest, eller genitalt trauma, där kvinnorna »kontrollerar" sitt blödande någon annanstans än i könsorganet - blir kanhända exkluderandet av männen begripligt. Tolkningen är minst sagt svår att applicera på män.

Självskadarna beskrivs i flera av de tidiga artiklarna som att de befinner sig i någon av ändarna på den sexuella erfarenhetsskalan, som antingen promiskuösa eller smärtsamt rädda för sex och det motsatta könet: horan eller madonnan. Den kvinnliga sexualiteten ses som lika patologisk som självskadebeteendet, åtminstone när den går utanför den traditionella strukturen. Självskadarna ses ofta som homosexuella, "pojkflickor", eller på andra sätt sexuellt nabnorma». Den traditionella könsstrukturen återfinns även som norm i tolkningen av självskadarnas familjeförhållanden: deras mödrar beskrivs ofta som dominanta och kalla, och fäderna som passiva och undertryckta. I Paos artikel framstår den arbetande modern och den skärande dottern som symptom på ett och samma problem: kvinnor som går utanför sina roller. Brickman tolkar Paos artikel, en aning tillspetsat, som att om inte mödrarna valde att arbeta och förändra sin ställning i samhället skulle deras döttrar slippa få en förvirrad sexuell identitet, och därmed också slippa skära sig i armarna (Brickman 2004 s. 99).

I dessa tidiga studier skapas förklaringsmodeller för självskadebeteende som i sig exkluderar möjligheten av ett manligt självskadebeteende, och där de killar och män som förekommer misstänks vara homosexuella, eller åtminstone sexuellt förvirrade. Brickman beskriver hur dessa studier på punkt efter punkt reproducerar en konservativ syn på den kvinnliga kroppen som skör och passiv, och där beteendet - som mycket väl kan betraktas som aktivt och "maskulint" - ses som ett uttryck för extrem passivitet, på sin höjd som "demi-aggressivt" (Brickman 2004). Tjejerna förnekas att överhuvudtaget vara förmögna att hysa 
aggressiva tankar och impulser, och beteendet ses som resultatet av en "normal feminin masochism». Att beteendet är feminint understryks ofta, och självskadaren är ständigt "attraktiv». Beteendet i sig ses som infantilt, som ett tecken på att dessa tjejer inte är fömögna att hantera sin adolescens. Själva termen "delicate» indikerar att självskadebeteendet förstör någonting högt värderat: angreppet på den åtrådda kvinnliga huden är ett angrepp på själva kvinnans väsen, vilket därmed per automatik måste vara patologiskt.

I artikeln »Female habitual self-mutilators» studerar Favazza och Conterio 240 kvinnor; de fjorton män som svarat på studiens enkät behandlas inte (Favazza \& Conterio 1989). Detta berörs dock i diskussionen: studien baseras på ett bekvämlighetsurval, och den stora delen vita kvinnor ska betraktas som just en konsekvens av urvalet. I senare arbeten noterar Favazza att viss försiktighet bör råda kring slutsatsen att självskadebeteende är ett problem förbehållet tjejer:

That the behaviour seems to be more common in females may be an artifact of sampling techniques. A tremendous amount of cutting and burning, for example, goes on in prison. In addition, males can easily lie about the causes of their scars (e.g., a result of a work injury, a fight, or a drunken fall) (Favazza 1996 s. 240).

Den försiktighet han manar till är dock sparsamt efterlevd - oftast refereras någon av de tidiga tongivande artiklarna eller någon som baseras på dessa för att fastslå beteendets könsfördelning. Även om Favaz- zas främsta text på området, Bodies Under Siege, är standardgods i referenslistorna tycks hans könsneutrala anslag gå de flesta förbi. Pattisons och Kahans (1983) artikel, "The Deliberate Self-Harm Syndrome», är ett annat av de fåtal exempel på ofta refererade artiklar där beteendet inte betraktas som feminint, något som generellt sett inte uppmärksammas då den refereras. Överlag tycks ifrågasättanden av den antagna könsfördelningen vara en blind fläck hos sentida forskare.

\section{Den svenska forskningen}

Socialstyrelsen fick 2003 i uppdrag av regeringen att studera flickor som medvetet skadar sig själva, ett uppdrag som resulterat i två rapporter, Flickor som skadar sig själva: En kartläggning av problemets omfattning och karaktär, samt Vad vet vi om flickor som skär sig? Titlarna anger vad de innehåller: den första är ett försök att kartlägga fenomenet, den andra är en genomgång av forskningen på området. Redan i regeringsuppdraget, och senare i titlarna, anges utgångspunkten: självskadebeteende är ett tjejproblem, och utifrån den premissen studeras det.

I den första rapporten, där enkäter skickats ut till vårdgivare och ungdomshem, konstateras att uppdraget inte omfattade pojkar, men att de kunnat identifiera en mindre grupp pojkar med motsvarande problem (Socialstyrelsen 2004a). Dessa tycks dock ha exkluderats ur studien. Enkäten som skickades ut, „Frågeformulär angående flickor födda 1984-1989 som skadat sig själv under år 2002«, är genomgående 
formulerad mot flickor (Socialstyrelsen 2004a, appendix 1 s. 27). Varje flicka som skadat sig ges ett eget formulär, där hennes situation grundligt ska redogöras för; psykiska och sociala problem, skolgång, tänkbara avsikter etc. Den sista frågan i enkäten frågar om personalen i verksamheten känner till några pojkar med samma beteende. I diskussionen konstateras att gruppen är "svårfångad", och att många hamnar utanför statistiken. Det görs ingen reflektion kring könsfördelningen på mörkertalet. Under rubriken "Genusperspektivet» står följande att läsa:

Tidigare undersökningar har $i$ allmänhet visat att själuskadebeteende $i$ tonåren är mer frekvent hos flickor än hos pojkar. Informanterna berättade även om pojkars självskador. Det finns ändå anledning att tro att självskadebeteende framförallt är en företeelse bland flickor. Det är sannolikt att beteendet, när det uppträder hos pojkar, kan ha en annan betydelse. Det är också troligt att många pojkar dämpar sin oro med mer aggressiva och utagerande metoder. Detta hindrar inte att det är viktigt att uppmärksamma att det finns en grupp pojkar som skadar sig på samma sätt som flickorna och som kanske upplever sig som mer udda och utsatta än flickorna (Socialstyrelsen 2004a s. 23).

Slutsatsen är att vi bör lyfta fram även de killar som skadar sig, då deras besvär kan vara än större. Tyvärr lyfts de inte fram, inte i Socialstyrelsens rapport, och ingen annanstans heller. I citatet framgår också att beteendet hos killar kan ha en annan betydelse. Vilken denna betydelse skulle kunna vara lämnas vi att spekulera i, liksom anledningen till varför betydelsen skulle vara en annan. Möjligen för att beteendet hos killar inte går att förklara med den förtryckande kvinnorollen, som föreslås för tjejerna. Det torde dock vara möjligt att tänka sig att en normativ mansroll skulle kunna fungera likartat, eller att normativa könsroller i sig är förtryckande.

I den andra av Socialstyrelsens rapporter finns en intressant avgränsning av uppdraget. I stycket beskrivs en mängd olika sätt på vilka en flicka kan skada sig själv: de kan förgifta sig, skära sig, bränna sig, missbruka alkohol, hetsäta, prostituera sig och tatuera sig. Avgränsningen görs genom de "yttre tecknen, självskadorna", på vilket sätt de skadar sig (Socialstyrelsen 2004b s. 10). Att de också avgränsat sig till endast ett av könen nämns inte. Resten av texten är en genomgång av den internationella litteraturen kring självskadebeteendets utbredning, orsaker och behandling, där könsaspekten inte ges något egentligt utrymme. Texten och beteendet - handlar om tjejer.

Stiftelsen Allmänna Barnhuset publicerade 2004 texten Unga som skadar sig själva, en skriftlig dokumentation från en konferens de anordnat i samarbete med Socialstyrelsen kring ungdomar med självskadebeteende. På ett par ställen beskrivs förekomsten av beteendet; vi får veta dels att självskadebeteende är ett dolt problem, då få självskadare söker vård, och samtidigt att det wär ett betydligt vanligare beteende hos flickor än bland pojkar» (Stiftelsen Allmänna Barnhuset 2004 s. 20). Det intressanta med påståendet är att textens huvudreferenser är Favazzas Bodies Under Siege och Pattisons och Kahans "The Deliberate 
Self-Harm Syndrome", från vilka en sådan slutsats svårligen kan dras. Den citerade meningen konstaterar även att vi inte vet mycket om förekomsten, då problemet är dolt, och att endast ett fåtal söker vård för sina skador.

I den inledande sammanfattningen till texten framställs skillnaden mellan könen som ett av de främsta områdena att studera, men ingenstans i de följande textena problematiseras denna aspekt. Då kön nämns som variabel konstateras det bara att beteendet är vanligast bland tjejer, utan någon referens. I flera av textena diskuteras problemet dessutom exklusivt ur ett tjejperspektiv:

För många människor har det varit en ny och omskakande kunskap - att till synes frisk a flickor, begåvade och med ordnade förhållanden, kan göra sig själva så illa (Stiftelsen Allmänna Barnhuset 2004 s. 47).

Den bild som här ges av den självskadande ungdomen är en karbonkopia av Graffs och Mallins sextiotalsstereotyp: den på ytan normala, intelligenta tjejen. Trots skriftens könsneutrala titel diskuteras självskadebeteende genomgående som ett tjejproblem. Killar nämns praktiskt taget inte, utöver konstaterandet att de istället för att skada sig själva »använder andra former av utagerande beteenden« (Stiftelsen Allmänna Barnhuset 2004 s. 10).

Att den nya kunskapen är så »omskakande» kan förklaras med att självskadebeteendet är ett angrepp på den femininitet som tjejerna förväntas efterleva; de skär bokstavligen sönder den hud de enligt en normativ femininitet borde ägna sin tid åt att putsa och vårda (Halberstam 1998). Det uppseendeväckande är inte beteendet i sig, utan att det utförs av tjejer. Beteendet skulle i en annan kontext kunna betraktas som maskulint, men då tjejerna antas vara de som skär sig hindras tolkningsmodellerna från att kliva ur femininitetsdiskursen. Därav förklaringarna att beteendet är feminint, inåtvänt, passivt och »demiaggressivt». Beteendet har genom det starka förknippandet med tjejer femininiserats, och forskningen har blivit inlåst i den feminina diskursen, där enbart vissa förklaringar är giltiga. Killarna, å sin sida, förblir oupptäckta, då ingen på allvar letar efter dem: efter ett slentrianmässigt konstaterande att beteendet tycks vara vanligast bland tjejer lämnas de eventuella killarna därhän. Tjejerna utgör inte slutsatsen - de är den icke ifrågasatta utgångspunkten.

En av de första texter som publicerades i Sverige som behandlar självskadebeteende Per Wallroths och Susanna Åkerlunds Hål i huden: Flickor som skär sig (2002). Denna text är ett tydligt exempel på tjejer som utgångspunkt snarare än slutsats. De använder sig i ett stycke kring "den typiska skäraren" av Graffs och Mallins ovan citerade beskrivning, och påpekar att den trots sin ålder fortfarande är relevant (Wallroth \& Åkerlund 2002 s. 14). De beskriver, med många referenser till artiklar från 1960- och 70-talen, självskadaren som en kvinna som antingen är promiskuös eller sexuellt oerfaren, med menstruationsångest och sexuellt förvirrad identitet. Det kan noteras att de refererar till Pattisons och Kahans artikel för att konstatera att beteendet är vanligare bland homosexuella. Pattison och Kahan hävdar att det bland mänär vanligare bland 
homosexuella, inte bland kvinnor (Pattison \& Kahan 1983). Den slutsatsen går å andra sidan väl ihop med bilden av beteendet som feminint, där de killar som förekommer oundvikligen måste femininiseras.

Forskningsgenomgången i studien baseras på referenser till tidigare forskning på området, och författarna tolkar egentligen inte denna forskning på något ohemult sätt. De påpekar dessutom att det finns studier som hävdar att fördelningen skulle vara mer jämn mellan könen, Pattisons och Kahans exempelvis, men att merparten av forskningen pekar på en övervikt för tjejer. Wallroth och Åkerlund talar uteslutande om "flickor", och många av de tolkningsmodeller som lyfts fram ur den tidigare forskningen är inriktade på tjejer, såsom problem med menstruationen.

Wallrots och Åkerlunds utgångspunkt är psykoanalytisk utvecklingspsykologi, där barndomstrauman utgör basen för det senare självskadebeteendet. En av de orsaker till beteendet som lyfts fram är bristande kontakt med föräldrarna, där rakbladet blir ett slags substitut för den frånvarande modern. Dödsdrift, trauma, bristande symboliseringsförmåga, könsidentitet och sexualitet är några av de psykoanalytiska områden som tillämpas på tjejerna i studien. Svårigheter med könsidentiteten och bristande moderskontakt framkommer som två av de mest centrala slutsatserna. Hela texten kretsar kring tjejer, och det görs ingen reflektion kring hur beteendet skiljer sig mellan könen. Noga räknat tycks sjävskadebeteende enbart existera hos ett kön. Detta är textens utgångspunkt, och det görs inga avsteg från den.

Margareta Samuelsson, socionom och psykoterapeut, har publicerat två artiklar i Socialmedicinsk tidskrift om självskadebeteende hos tonårstjejer (Samuelsson 2001, Samuelsson 2004). Båda artiklarna utgår från att beteendet är vanligast bland tjejer, och i likhet med många andra artiklar problematiseras inte detta antagande nämnvärt. Samuelsson skriver att det är intressant att studera, förutom den generella ökningen,

varför beteendet förekommer mer hos flickor än hos pojkar, undersöka om det är ett samhällsfenomen med gemensam kollektiv stress på flickrollen just nu med dålig självkänsla som följd och framförallt försöka förstå hur dessa ungdomar mår psykiskt och vad som har påverkat dom till detta beteende (Samuelsson 2001 s. 450).

Det är värt att notera att hon inte skriver om beteendet förekommer mer hos flickor än hos pojkar, utan varför. Tjejerna är utgångspunkten, i artikeln framstår könsfördelningen som ett faktum. I den andra artikeln nöjer hon sig med att referera till sin förra artikel för konstaterandet att beteendet främst utförs av tjejer (Samuelsson 2004).

\section{Den idealtypiska berättelsen kring självskadebeteende}

I forskningen har det skapats en idealtypisk bild av den självskadande ungdomen, vars sinnebild är den vita, psykiskt labila, sköra tonårstjejen. Denna bild blir ett fundament för skapandet av en idealtypisk berättelse kring självskadebeteende, en berättelse som är ett viktigt element i den självska- 
dande ungdomens identitetsbildning. Berättelsen blir här en identitetsprocess, där den idealtypiska bilden av den självskadande tjejen fungerar som ett ständigt närvarande identitets- och sjukdomsideal. På så sätt blir dessa ungdomars identiteter institutionaliserade, och den idealtypiska bilden och berättelsen blir i sig självuppfyllande. Att betrakta självskadebeteende som feminint är ett steg i processen att göra kön. Att ansluta sig till den stereotypa bilden av den självskadande tjejen gör det lättare att anamma, om inte den önskvärda så åtminstone någon identitet. Identiteten blir dessutom alltmer socialt accepterad i samband med att stereotypen etableras. Att ansluta sig till stereotypen blir en lättnad, då det ger ett sammanhang och en känsla av hemkomst: det finns fler som är som jag.

Att ansluta sig till den idealtypiska berättelsen kring självskadebeteende går också att se som ett slags överlevnadsstrategi. Att leva upp till den etablerade bilden blir ett sätt att få tillgång till den hjälp som utformats - och som i hög grad ses som prioiterad att utforma tydligare - för den stereotypa självskadaren. Detta kan ske såväl omedvetet som medvetet, exempelvis genom att anamma symptom i olika diagnoskriterier, något som ofta sker med nya diagnoser:

När diagnosen väl finns - som namn och som bild - medicinskt och kulturellt legitimerad och medialt exponerad, tenderar den att dra till sig bärare av den typiska symtombilden (Johannisson 2006 s. 31).

Detta gäller i hög grad för självskadebeteende. Den mediala exponeringen har varit tämligen omfattande, vilket rimligen inneburit en ökning av antalet ungdomar som tagit till sig beteendet.

Killar med självskadebeteende utmanar emellertid idealtypen. Eftersom de inte uppfyller könskriteriet för den kan de svårligen använda den på samma sätt som tjejerna. Den bild killarna istället har att laborera med är den lika idealiserade bilden av den utåtagerande, kriminelle killen. Denna idealtyp är kanske ännu enklare att på ett övertygande sätt ansluta sig till, då »symptomen" är extroverta och lättigenkänneliga. Killar med självskadebeteende är, som en följd av de könsbundna idealiserade bilderna av ungdomar med "problem", svårare att upptäcka, eftersom de står utanför såväl den feminina idealtypen kring självskadebeteende som den maskulina idealtypen kring den utåtagerande killen. De bryter mot maskulinitetsnormen, men normbrottet uppmärksammas inte, då de inte gör tillräckligt mycket väsen av sig. Motsvarande normbrott hos tjejer uppmärksammas på ett annat sätt, då deras avsteg från den feminina inåtvända idealtypen innebär att de blir utåtagerande: de syns och hörs.

Det är viktigt att här påpeka att killars självskadebeteende inte bara kan avfärdas som enstaka normbrott. Det centrala är hur beteendet tolkas olika beroende på vem det är som utför det, en tjej eller en kille. Maskulinitet och femininitet är därför främst kopplat till uppfattningar kring beteenden snarare än till beteendena i sig själva. Teoretiskt skulle fördelningen kunna vara den omvända mot vad som antas i många studier, med en överrepresentation av killar, medan den idealtypiska bilden av den självskadande ungdomen fortfarande skulle 
kunna vara en tjej. En sådan bild accentuerar och bekräftar självskadebeteendet som ett inåtvänt och feminint problem, som därför hänförs till det kvinnliga könet.

\section{Slutsats}

Merparten av forskningen, och även den massmediala rapporteringen, lutar sig mot den idealtypiska berättelsen om den självskadande tonårstjejen när ämnet självskadebeteende berörs. Oavsett om könsfördelningen är skev eller jämn - ingen vet hur den egentligen ser ut - får denna bild konse- kvenser. Den får konsekvenser för tjejerna, då de låses in $\mathrm{i}$ en normativ femininitet som i sig möjligen kan frammana psykiska problem och självskadebeteende. Den får konsekvenser för killarna, eftersom många studier exkluderar dem, avfärdar dem och vägrar att se dem, vilket i sin tur innebär att vårdutbudet $i$ än högre grad kommer att utformas specifikt för tjejer. Den idealtypiska berättelsen får slutligen också konsekvenser för den allmänna förståelsen av problemet, då denna drabbats av det Wittgenstein kallade aspektblindhet: vi ser inte killarna eftersom vi bara stirrar på tjejerna.

\section{Referenser}

Andersson, B. (1997) Ett \$12-hem för flickor. Omdefinitioner i ungdomsvården, Research Reports, 1997:1. Lund: Sociologiska institutionen.

Brickman, B. J. (2004) "Delicate' Cutters: Gendered Self-mutilation and Attractive Flesh in Medical Discourse", Body \& Society, vol. 10(4), s. 84-111.

BRIS (2005) BRIS-rapporten 2004. BRIS.

Eriksson, A. F. (2005) Ledarskap och kön: En studie av ledare och maskuliniteter i ett verkstadsindustriföretag. Linköping: Linköpings universitet.

Favazza, A. R. (1996) Bodies under Siege: SelfMutilation and Body Modification in Culture and Psychiatry. Baltimore: The Johns Hopkins University Press.

Favazza A. R. \& Conterio K. (1989) „Female habitual self-mutilators", Acta Psychiatrica Scandinavica, 79, pp. 283-289.

Graff, H. \& Mallin, R. (1967) "The Syndrome of the Wrist Cutter", American Journal of Psychiatry, 124(1), pp. 36-41.
Halberstam, J. (1998) Female masculinity, London: Duke University Press.

Hilte, M. \& Claezon, I. (2005) Flickor och pojkar på institution - ett könsperspektiv på vården av ungdomar. Rapport 2005:4. Stockholm: Stiftelsen Allmänna Barnhuset.

Johannisson, K. (2006) »Hur skapas en diagnos? Ett historiskt perspektiv«. I G. Hallerstedt (red.) Diagnosens makt: Om kunskap, pengar och lidande. Göteborg: Daidalos.

Matsumoto T, Yamaguchi A, Asami T, Okada T, Yoshikawa K \& Hirayasu Y (2005) "Characteristics of self-cutters among male inmates: Association with bulimia and dissociation", Psychiatry and Clinical Neurosciences, 59, pp. 319-326.

Nordberg, M. (2004) „'Kvinnlig maskulinitet' och 'manlig femininitet'. En möjlighet att överskrida könsdikotomin?", Kvinnovetenskaplig tidskrift, 1-2 2004, s. 47-65.

Pao, P-N. (1969) »The Syndrome of Delicate Self- 
cutting", British Journal of Medical Psychology 42, pp. 195-206.

Pattison, E. M. \& Kahan, J. (1983) »The deliberate self-harm syndrome", American Journal of Psychiatry, 140; pp. 867-872.

Rosenthal R J, Rinzler C, Wallsh R \& Klausner E (1972) "Wrist-cutting Syndrome: The Meaning of a Gesture", American Journal of Psychiatry 128(11), pp. 1363-1368.

Samuelsson, M. (2001) „Självskadebeteende ett fenomen hos tonårsflickor: En litteraturgenomgång över bakomliggande faktorer", Socialmedicinsk tidskrift (78) 5, s. 449-454.

Samuelsson, M. (2004) "Självskadebeteende hos unga kvinnor: Litteraturredovisning av nyare artiklar rörande självskadebeteende, dess bakgrund och behandling", Socialmedicinsk tidskrift (81) 3, s. 271-277.

Sandberg, B. (2001) „Psykisk hälsa». I B. Marklund (red.) Ungdomars liv och hälsa i Halland, FoUenheten, Primärvården i Halland.

Simeon, D. \& Favazza, A. R. (2001) "Self-Injurious Behaviors: Phenomenology and Assessmentu. I D. Simeon \& E. Hollander (eds) Self-Injurious Behaviors: Assessment and Treatment. Wash- ington: American Psychiatric Publishing, Inc.

Socialstyrelsen (2004a) Flickor som skadar sig själva: En kartläggning av problemets omfattning och karaktär. Stockholm: Socialstyrelsen.

Socialstyrelsen (2004b) Vad vet vi om flickor som skär sig? Stockholm: Socialstyrelsen.

Socialstyrelsen (2005) Folkhälsorapport 2005. Stockholm: Socialstyrelsen.

Socialstyrelsen (2006) Skador och förgiftningar behandlade i sluten vård 2003. Stockholm: Socialstyrelsen.

Stiftelsen Allmänna Barnhuset (2004) Unga som skadar sig själva: En belysning av forskningsläget. Rapport 2004:1. Stockholm: Stiftelsen Allmänna Barnhuset.

Taylor, B. (2003) "Exploring the perspectives of men who self-harm", Learning in Health and Social Care, 2, pp. 83-91.

Wallroth, P. \& Åkerlund, S. (2002) Hål i huden: Flickor som skär sig, Svenska föreningen för psykisk hälsa.

Överlien, C. (2006) »Institutionen som arena för skapandet av en sexuell identitet. Samtal från ett särskilt ungdomshem", Socialvetenskaplig Tidskrift, nr 2, s. 164-178.

\section{Summary}

\section{The mythology of self-mutilation: Gendered stereotypes and ideal-typical stories}

The article seeks to investigate a common conclusion in studies of self-mutilation: the mutilator as an attractive, white teenage girl. This aim is attained by reading early influential psychiatric studies on the topic, and comparing them to the small amount of
Swedish research available. The conclusion reached is that neither the international nor the Swedish research can verify the notion that the behaviour is more prevalent among females than among males. This conclusion is nevertheless constantly drawn, and the

Christian Ståhl: Det mytologiska självskadebeteendet. 
available interpretations of the meaning of the behaviour are highly influenced by gendered assumptions about masculine and feminine behaviour.

This results are analysed using theories about masculinity and femininity and the concept of doing gender: how the sexes are "made» in social interaction between people and structures. Gender, as well as concepts of masculinity and femininity, are results of social processes. Masculinity, while being a concept equally present in males and females, is generally connected with the male body and person in the same way femini- nity is connected to females. The ideas of masculinity and femininity help to create normative gendered discourses, in which identity-seeking adolescents internalize their gender identity.

The discourse of femininity is crucial to how the understanding of self-mutilation was established in the articles of the 1960s and 1970s. Concepts of femininity are equally important in more recent Swedish research, where the image of the self-mutilator as a teenage girl seems to be more of a starting point than a conclusion. 